\title{
Evaluating harvest costs and profit of commercial thinnings in softwood stands in west-central Maine: A case study
}

\author{
by Patrick Hies ${ }^{1 *}$, Jeffrey G. Benjamin² and Brian E. Roth ${ }^{3}$
}

\begin{abstract}
Precommercial thinning (PCT) is a common silvicultural treatment in the management of young conifer forests. The positive effects of PCT on tree growth are well documented, however, there have been few operational studies of thinning productivity associated with later harvests in such stands and associated cost comparison with high-density, small-diameter stands. In the winters of 2012/2013 and 2013/2014 a long-term herbicide and PCT study in west-central Maine was commercially thinned using cut-to-length (CTL) and whole-tree (WT) harvesting systems in PCT and non-PCT stands, respectively. Thinning prescriptions consisted of three nominal removal intensities $(33 \%, 50 \%$, and $66 \%$ of the standing softwood volume) in a randomized block design with three to four replications. Stand density, basal area, hardwood content, and removal intensity were not significant in explaining variation in harvester and feller-buncher productivity. An analysis of unit cost of production indicated that wood chip production using a WT system in non-PCT stands is less costly than the production of roundwood using a CTL system in PCT stands. Profit, however, is similar for products harvested by either system. Our conclusion is that the WT system used in the study is economically feasible to treat highdensity, small-diameter stands in a commercial thinning.
\end{abstract}

Keywords: PCT, non-precommercial thinning, NPCT, New England, harvester, feller-buncher, Ponsse Ergo, CAT 501

\section{RÉSUMÉ}

On recourt souvent à léclaircie précommerciale (ÉPC) pour traiter les jeunes peuplements de résineux. Si les effets positifs de ce traitement sont bien documentés, on compte peu d'essais opérationnels comparant la productivité et les coûts de léclaircie combinée avec la récolte tardive dans ces mêmes peuplements à ceux pour les peuplements de forte densité et de faible diamètre. Durant les deux hivers de 2012/2013 et 2013/2014, on a effectué une éclaircie commerciale dans un bloc expérimental traité par ÉPC combinée à l'application d'herbicide dans le centre-ouest du Maine; la coupe sest effectuée avec la méthode par bois court (BC) dans l'ÉPC, et par arbre entier (AE) dans les peuplements non éclaircis. Les règles déclaircie comportaient trois niveaux initiaux de prélèvement (33\%, $50 \%$, et $66 \%$ du volume de résineux sur pied) dans un dispositif de blocs aléatoires avec trois ou quatre répétitions. La densité du peuplement, la surface terrière, le contenu en feuillus et le niveau de prélèvement n’ont pas affecté significativement la productivité de l'abatteuse-façonneuse et de l'abatteuse-groupeuse. Lanalyse du coût unitaire de production a montré qu'il en coûte moins de produire des copeaux avec le système par AE que des billots avec le système par BC dans les peuplements éclaircis. Cependant, le profit aura été le même dans les deux cas. Nous en concluons qu'il est économiquement faisable d'utiliser la méthode de l'AE décrite dans létude pour effectuer une éclaircie commerciale dans les peuplements de forte densité et de faible diamètre.

Mots-clés : ÉPC, éclaircie non précommerciale, ÉNPC, Nouvelle-Angleterre, abatteuse-façonneuse, abatteuse-groupeuse, Ponsse Ergo, CAT 501

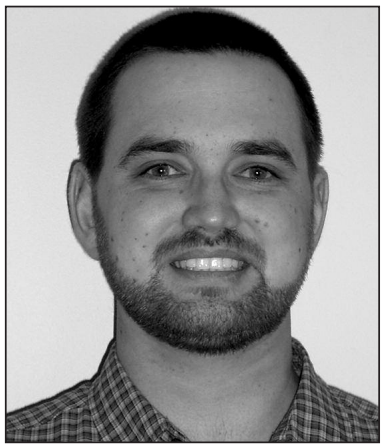

Patrick Hiesl

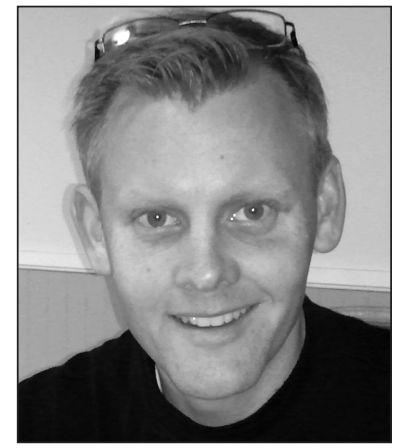

Jeffrey G. Benjamin

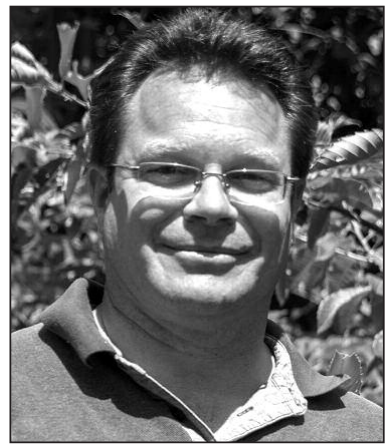

Brian E. Roth

\footnotetext{
${ }^{1}$ University of Maine, 5755 Nutting Hall, Orono, ME 04469; * Corresponding author: patrick.hiesl@maine.edu

${ }^{2}$ University of Maine, 5755 Nutting Hall, Orono, ME 04469, jeffrey.g.benjamin@maine.edu

${ }^{3}$ Cooperative Forestry Research Unit, 5755 Nutting Hall, Orono, ME 04469, brian.roth@maine.edu
} 


\section{Introduction}

Precommercial thinning (PCT) is a common silvicultural treatment used in the early management of conifer forests across North America and Europe (Zhang et al. 2006, Olson et al. 2012, Bataineh et al. 2013,). The effects of PCT on tree growth have been investigated and documented for a wide range of forest types (Balmer et al. 1978, Brissette et al. 1999, Zhang et al. 2006, Pitt and Lanteigne 2008, Olson et al. 2012, Bataineh et al. 2013), however, this treatment represents a significant financial investment by the landowner which must be carried many years before a commercial harvest. Long-term results of growth responses and financial returns by PCT treatments are limited in the Acadian forest region (Saunders et al. 2008, Bataineh et al. 2013, Pitt et al. 2013b). Results from a 40-year spruce-fir (Picea rubens Sarg., Abies balsamea (L.) Mill.) study in west-central Maine involving a combination of early herbicide and PCT show that 13 to 24 years following PCT, the diameter and height increment was greater than that for non-PCT trees (Bataineh et al. 2013). The authors further reported that the total stumpage value of PCT stands was on average USD \$907/ha higher than for non-PCT stands of the same age. A long-term PCT study from New Brunswick, Canada found that PCT increased diameter growth rates with responses proportional to the thinning intensity (Pitt et al. 2013a). Half the plots were clearcut in 2008 at ages 55 and 62, and results showed that harvester productivity increased in proportion to PCT intensity due to the positive effect of PCT on average stem size (Plamondon and Pitt 2013). Another benefit of PCT is that it can increase regeneration and thus function similar to a shelterwood establishment cut (Olson et al. 2014). This study was conducted in Maine and shows that the abundance of medium (0.61-1.40 m tall) and large $(\geq 1.41 \mathrm{~m}$ tall to $9.90 \mathrm{~cm}$ $\mathrm{dbh}$ ) softwoods increased with increasing thinning intensity.

Typically, a commercial thinning (CT) is prescribed many years after PCT to further improve residual stand conditions and stand growth and yield (Smith 1986, Pekol et al. 2012). Clune (2013) studied spruce-fir response to a combination of commercial thinning methods, timings and intensities of removal over the past decade in Maine, with results showing the benefit of CT on stand stability and growth. CT has been shown to focus diameter and volume growth on a selected number of stems and therefore decreases the growing time to a specific merchantable volume (Pelletier and Pitt 2008).

Maine consists of millions of acres of small-diameter forest land (McCaskill et al. 2011) that either are in need of PCT or have already passed the right time for an economical treatment. One of the challenges regarding such stands is to determine how they can be operationally treated in a cost-effective manner to increase growth and yield of individual trees. During the winters of 2012/2013 and 2013/2014, the long-term Austin Pond study in west-central Maine (Newton et al. 1992a, 1992b), which began as a herbicide screening trial and was later expanded into a long-term PCT study, received a first-entry commercial thinning. Two stand conditions were harvested: (1) a 42-year-old stand that received PCT at age 16 and, (2) a 43-year-old stand that did not receive a PCT treatment. Three different thinning intensities were prescribed with three to four replicates (non-PCT and PCT respectively) in a randomized block design. Harvest systems were matched to stand conditions with a cut-to-length system assigned to harvest PCT stands and a whole-tree system assigned to nonPCT stands. The harvest systems chosen are currently operational in Maine and represent one possible combination of equipment to conduct a CT in the described stands. Our first objective was to compare productivity of harvester and fellerbuncher operating with three different removal intensities. The second objective was to compare the harvest costs and profit of CT in PCT and non-PCT stands to assess the economic feasibility of such a treatment.

\section{Methods \\ Site}

Detailed information about the Austin Pond study site are described in the publications of Newton et al. 1992a, 1992b; Bataineh et al. 2013. The study site is located in Somerset County, Maine $\left(45.20^{\circ} \mathrm{N}, 69.70^{\circ} \mathrm{W}\right)$. Mean annual precipitation is $100 \mathrm{~cm}$ with $40 \%$ occurring from June through September. The site was clear-cut in 1970 and an herbicide screening trial designed to release naturally regenerated conifers from competing hardwoods was installed seven years later. Sixteen years after the harvest, each herbicide treatment unit (approximately 1 ha) was split, with one half pre-commercially thinned to approximately 1730 trees/ha. In 2012, 21 measurement plots $\left(809 \mathrm{~m}^{2}\right)$ were installed in a subset of the original herbicide $\times$ PCT treatment units. Species, diameter at breast height (dbh), total height, and height to the base of the live crown were recorded for all trees $>7.6 \mathrm{~cm}$ in $\mathrm{dbh}$. Mean dbh for PCT stands ranged from $13.1 \mathrm{~cm}$ to $18.7 \mathrm{~cm}$ with stand densities ranging from 1309 to 2594 trees/ha (Table 1). For non-PCT stands, mean dbh ranged from $9.6 \mathrm{~cm}$ to $12.8 \mathrm{~cm}$ with stand densities ranging from 3211 to 5496 trees/ha (Table 1). Based on the number of stems, all stands were dominated by balsam fir (Abies balsamea (L.) Mill.) and consisted of $4 \%$ and $28 \%$ red spruce (Picea rubens Sarg.), $1 \%$ to $30 \%$ quaking aspen (Populus tremuloides Michx.), and up to $35 \%$ of other species such as paper birch (Betula papyrifera Marshall), yellow birch (Betula alleghaniensis Britt.), eastern white pine (Pinus strobus L.), and northern white cedar (Thuja occidentalis L.). Individual treatment units ranged in size from 0.40 to 0.71 ha (Table 1 ).

\section{Experimental Design}

Three different thinning prescriptions were implemented with three to four replicates across non-PCT and PCT-treated stands (Table 2). Nominal thinning prescriptions were to remove $33 \%, 50 \%$, or $66 \%$ of the standing softwood volume using a modified thinning from below prescription, which included the removal of large balsam fir $(\mathrm{dbh}>20 \mathrm{~cm})$ to ensure utilization of such trees before butt rot will decrease their value (Seymour 1995, Tian 2002). To achieve this goal, a computer program developed by the Cooperative Forestry Research Unit at the University of Maine was used to mark individual trees in the field. The program used regional volume equations to accurately calculate the total volume removed as trees are marked for removal to reach the target removal percentage for each plot.

The blocking of individual treatment units with one of the three prescriptions was based on relative stand density (RD) and the quadratic mean diameter (QD). An analysis of stand information showed that several groups with similar $\mathrm{RD}$ and $\mathrm{QD}$ values existed. In each of these groups the prescriptions 


\begin{tabular}{|c|c|c|c|c|c|c|c|c|c|}
\hline Plot & Block & $\begin{array}{l}\text { Treatment } \\
\text { unit (ha) }\end{array}$ & $\begin{array}{c}\text { Mean } \\
\text { dbh } \\
(\mathrm{cm})\end{array}$ & $\begin{array}{l}\text { Mean } \\
\text { height } \\
(\mathbf{m})\end{array}$ & $\begin{array}{l}\text { Mean } \\
\text { height } \\
\text { to crown } \\
(\mathbf{m})\end{array}$ & $\begin{array}{c}\text { Stand } \\
\text { density } \\
\text { (trees/ha) }\end{array}$ & $\begin{array}{c}\text { Basal area } \\
\left(\mathrm{m}^{2} / \mathrm{ha}\right)\end{array}$ & $\begin{array}{l}\text { Piece size } \\
\quad\left(\mathbf{m}^{3}\right)\end{array}$ & $\begin{array}{c}\text { Hardwood } \\
\text { component } \\
(\%)\end{array}$ \\
\hline \multicolumn{10}{|c|}{ PCT Treatments } \\
\hline $1 \mathrm{~T}$ & $\mathrm{~T} 1$ & 0.57 & 13.7 & 12.8 & 7.2 & 2334 & 37.7 & 0.08 & 35 \\
\hline $3 \mathrm{~T}$ & $\mathrm{~T} 2$ & 0.61 & 15.6 & 12.3 & 6.2 & 1778 & 36.7 & 0.11 & 3 \\
\hline $4 \mathrm{~T}$ & $\mathrm{~T} 3$ & 0.49 & 13.1 & 11.7 & 6.4 & 2470 & 36.8 & 0.07 & 22 \\
\hline $7 \mathrm{~T}$ & $\mathrm{~T} 2$ & 0.61 & 13.9 & 11.3 & 4.5 & 1581 & 26.0 & 0.08 & 9 \\
\hline $10 \mathrm{~T}$ & $\mathrm{~T} 2$ & 0.45 & 18.7 & 13.5 & 6.4 & 1309 & 37.6 & 0.17 & 0 \\
\hline $11 \mathrm{~T}$ & $\mathrm{~T} 4$ & 0.53 & 14.1 & 10.8 & 4.2 & 1618 & 27.3 & 0.08 & 1 \\
\hline $12 \mathrm{~T}$ & $\mathrm{~T} 1$ & 0.40 & 12.5 & 12.1 & 6.2 & 2495 & 33.5 & 0.06 & 32 \\
\hline $15 \mathrm{~T}$ & $\mathrm{~T} 4$ & 0.49 & 14.0 & 12.8 & 6.9 & 2198 & 37.1 & 0.09 & 23 \\
\hline $17 \mathrm{~T}$ & $\mathrm{~T} 4$ & 0.49 & 15.2 & 13.4 & 7.3 & 2062 & 41.4 & 0.12 & 16 \\
\hline $21 \mathrm{~T}$ & $\mathrm{~T} 3$ & 0.61 & 13.4 & 12.1 & 6.5 & 2594 & 41.4 & 0.08 & 24 \\
\hline $23 \mathrm{~T}$ & $\mathrm{~T} 3$ & 0.45 & 14.2 & 12.7 & 6.8 & 2297 & 40.6 & 0.09 & 16 \\
\hline $27 \mathrm{~T}$ & $\mathrm{~T} 1$ & 0.57 & 15.4 & 13.1 & 7.1 & 1976 & 42.0 & 0.13 & 18 \\
\hline \multicolumn{10}{|c|}{ Non-PCT Treatments } \\
\hline $2 \mathrm{U}$ & $\mathrm{U} 1$ & 0.49 & 10.6 & 11.2 & 7.2 & 4162 & 40.7 & 0.04 & 21 \\
\hline $4 \mathrm{U}$ & $\mathrm{U} 1$ & 0.40 & 10.5 & 11.2 & 6.5 & 4211 & 41.5 & 0.04 & 27 \\
\hline $10 \mathrm{U}$ & U3 & 0.49 & 11.0 & 11.2 & 6.7 & 3668 & 39.2 & 0.05 & 23 \\
\hline $13 \mathrm{U}$ & $\mathrm{U} 2$ & 0.61 & 9.8 & 10.4 & 6.4 & 5496 & 45.6 & 0.03 & 14 \\
\hline $16 \mathrm{U}$ & U3 & 0.57 & 12.8 & 13.0 & 8.5 & 3211 & 47.6 & 0.08 & 7 \\
\hline $18 \mathrm{U}$ & $\mathrm{U} 2$ & 0.65 & 9.6 & 10.2 & 6 & 5372 & 42.8 & 0.03 & 10 \\
\hline $22 \mathrm{U}$ & U2 & 0.71 & 10.2 & 10.9 & 7.2 & 5483 & 49.8 & 0.04 & 2 \\
\hline $24 \mathrm{U}$ & U3 & 0.53 & 11.1 & 11.3 & 7.2 & 3507 & 38.6 & 0.04 & 37 \\
\hline $27 \mathrm{U}$ & U1 & 0.49 & 10.9 & 11 & 6.4 & 3668 & 38.7 & 0.04 & 15 \\
\hline
\end{tabular}

Table 2. Nominal description of three prescriptions across PCT and non-PCT stands. The prescription was marked without the inclusion of trails. Due to this exclusion the effective removal is larger than the prescription indicates. The three prescriptions consist of a thinning from below with the addition of removing large balsam fir ( $\mathrm{dbh}>20 \mathrm{~cm}$ ).

\begin{tabular}{|c|c|}
\hline Prescription & Description \\
\hline $33 \%$ & $\begin{array}{l}\text { Removal of } 33 \% \text { of softwood volume, with } 100 \% \\
\text { removal of hardwoods. Softwoods are to be } \\
\text { thinned to } 3.0 \mathrm{~m} \text { to } 4.6 \mathrm{~m} \text { spacing for PCT stands } \\
\text { and } 2.4 \mathrm{~m} \text { to } 3.0 \mathrm{~m} \text { spacing for non-PCT stands. } \\
\text { Priority for retention: RS > WP > WC > BF }\end{array}$ \\
\hline $50 \%$ & $\begin{array}{l}\text { Removal of } 50 \% \text { of softwood volume, with } 100 \% \\
\text { removal of hardwoods. Softwoods are to be } \\
\text { thinned to } 3.0 \mathrm{~m} \text { to } 4.6 \mathrm{~m} \text { spacing for PCT stands } \\
\text { and } 2.4 \mathrm{~m} \text { to } 3.0 \mathrm{~m} \text { spacing for non-PCT stand. } \\
\text { Priority for retention: RS > WP > WC >BF }\end{array}$ \\
\hline $66 \%$ & $\begin{array}{l}\text { Removal of } 66 \% \text { of softwood volume, with } 100 \% \\
\text { removal of hardwoods. Softwoods are to be } \\
\text { thinned to } 3.0 \mathrm{~m} \text { to } 4.6 \mathrm{~m} \text { spacing for PCT stands } \\
\text { and } 2.4 \mathrm{~m} \text { to } 3.0 \mathrm{~m} \text { spacing for non-PCT stands. } \\
\text { Priority for retention: RS > WP > WC > BF }\end{array}$ \\
\hline
\end{tabular}

Note: $\mathrm{RS}=$ red spruce, $\mathrm{WP}=$ eastern white pine, $\mathrm{WC}=$ northern white cedar, $\mathrm{BF}=$ balsam fir were randomly assigned. This approach ensured that each prescription was implemented across a variety of $\mathrm{RD}$ and $\mathrm{QD}$ conditions.

As the Austin Pond study is predominantly a softwood research project, the prescription further included the removal of all hardwood trees unless they would fill a gap in the stand. All crop trees were marked before the thinning, and harvest trails were overlaid using a trail spacing of $15.2 \mathrm{~m}$ (centre of trail to centre of trail). Therefore as a result, the effective total removal of softwood volume is greater than the nominal prescription indicates.

The nominal thinning prescriptions resulted in basal area removals of $33 \%$ to $75 \%$, and $57 \%$ to $80 \%$ in PCT and nonPCT stands, respectively. Prescriptions for thinnings in excess of $50 \%$ of the basal area are not common in this region, however, such high removal intensities increase the amount of softwood regeneration (Olson et al. 2014). The highest removal intensities therefore represent an extreme entry that will be used to gain information about stand responses to such a treatment in future research projects.

\section{Equipment Selection}

PCT treatment units were thinned using a cut-to-length harvesting system consisting of a Ponsse Ergo harvester and a Timberjack 1110 forwarder. This system was chosen for its efficiency in thinning operations, the narrow trail width nec- 
essary, and availability of the contractor at the time of harvest. Non-PCT treatment units were thinned using a whole-tree harvesting system consisting of a CAT 501 feller-buncher and a John Deere 648 GIII grapple skidder. The CAT 501 fellerbuncher was chosen for its narrow track width and small machine size. Although this machine is not widely used in Maine, its productivity data in similar high density stands showed a great potential for economically feasible thinnings (Benjamin et al. 2013). Unpublished data from research conducted by Benjamin et al. (2013) and Hiesl (2013) in this region further showed that cut-to-length systems commonly used in Maine were not cost efficient in thinning high density small diameter softwood stands such as the non-PCT stands in this study. A truck mounted Prentiss 325 loader was used to load roundwood trucks and to feed a Morbark Model 23 disk chipper.

Equipment operators in this study had between seven and thirty years of experience working in similar stand conditions. Experienced operators were chosen to minimize resid- ual stand damage and to ensure high harvest productivity, as the operator can have a large effect on machine productivity (Kärhä et al. 2004, Purfürst and Erler 2011, Hiesl 2013, Hiesl and Benjamin 2013a).

\section{Measurements}

Twelve PCT and nine non-PCT treatment units were thinned by the harvester and feller-buncher, respectively. During active operations, machine operators were required to maintain a record of harvesting time for each treatment unit including delays less than 15 minutes. Due to the randomized harvest design, up to three treatment units were situated in one row with trails running their length (Fig. 1). As the travel time from one trail to another trail would be greater for the second and third unit in a row, the machine operators were asked to only record the productive time from the harvest unit boundary onwards. This ensured that only times that were associated with the immediate thinning were recorded and analyzed. Wood extraction time (e.g., forwarder and

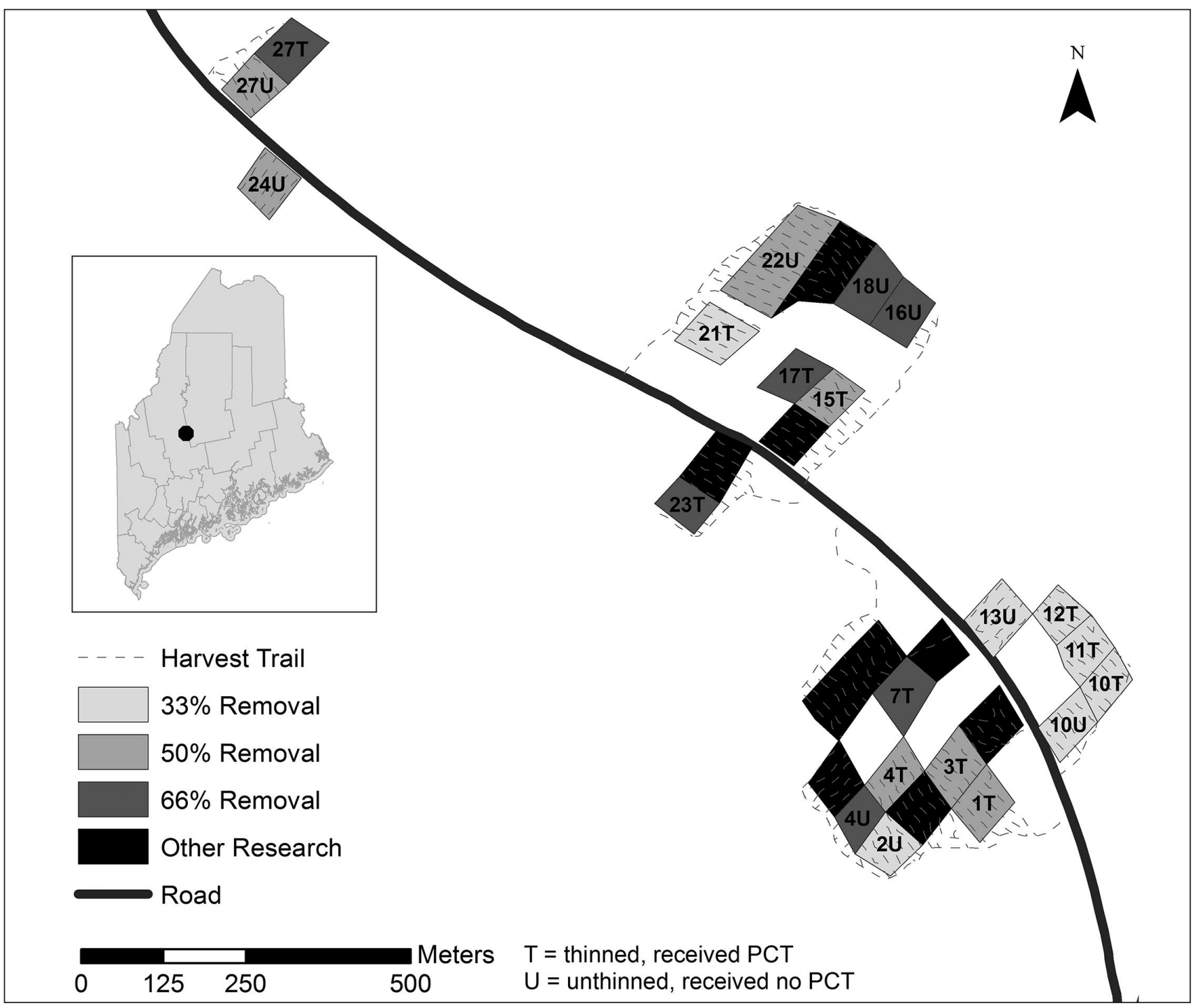

Fig. 1. Map of Austin Pond harvest layout for PCT and non-PCT treatment units in Somerset County, Maine (45.20 $\mathrm{N}, 69.70^{\circ} \mathrm{W}$ ). Three prescriptions were applied to PCT and non-PCT treatment units. Plot numbers followed by a 'T' received a PCT treatment in 1986 while those followed by a 'U' did not. PCT stands were harvested in 2013 with a cut-to-length system while non-PCT plots were harvested with a whole-tree system. 
skidder) was modelled using regional cycle time equations (Hiesl 2013, Hiesl and Benjamin 2013b).

Three different products were processed by the harvester: spruce/fir pulpwood $(3.6 \mathrm{~m})$, spruce/fir saw logs in three lengths $(3.6 \mathrm{~m}, 4.3 \mathrm{~m}, 4.9 \mathrm{~m})$, and tree-length hardwood pulpwood. To ensure accurate measurements of the harvested volume, we asked the forwarder and skidder operators to separate each product at the landing by harvest plot. Individual $\log$ and whole-tree piles were painted with the plot number for later reference.

These piles were measured (width $\times$ length $\times$ height) at the landing for plot-level volume before being trucked to the mill. The plot-level fractions of total wood harvested were later multiplied by the mill-delivered total to estimate millscaled removals from each harvest unit. This approach was deemed to be more efficient than weighing a sub-sample of each plot in the field based on results from Benjamin et al. (2013). All roundwood was transported and scaled within two days of harvest. Total weight measured in short tons, as determined from mill scales, was converted to metric tonnes using a conversion factor of 0.907 tonnes/ton. Productivity (tonnes/PMH) for the harvester and feller-buncher per treatment unit was then calculated (Table 3).

\section{Unit Cost of Production}

Hourly machine costs were developed using the approach outlined by Brinker et al. (2002). The machine rates used in this paper refer to the costs to own and operate a piece of equipment, however they do not include other business related expenses (e.g., moving of equipment, service trucks, administration). Machine rates for the Ponsse Ergo harvester,
CAT 501 feller-buncher, Timberjack 1110 forwarder, and John Deere 648 GIII grapple skidder were adapted from unpublished data of an early commercial thinning study by Benjamin et al. (2013). Loader and chipper rates were supplied by an anonymous source and are representative of regional rates between 2011 and 2014 (Table 4). The total unit cost of production includes the costs of wood products from stump to mill.

Unit cost calculations for the harvester and feller-buncher were based on the productivity measured in each harvest unit. As the forwarding and skidding times were not measured, we used regional cycle time equations (Hiesl 2013, Hiesl and Benjamin 2013b) to estimate extraction times. In this analysis, we assumed that each harvest unit consisted of five trails with a maximum distance to the landing of $210 \mathrm{~m}, 240$ $\mathrm{m}, 250 \mathrm{~m}, 270 \mathrm{~m}$, and $280 \mathrm{~m}$. For each trail, $75 \mathrm{~m}$ were within the harvest unit while the remaining distance was from the landing to the beginning of the harvest unit. These assumptions ensured the accurate comparison of thinning productivity and costs between the individual treatments.

The number of loads per treatment unit for the forwarder was calculated based on the harvested volume. For this calculation we used the average piece size of each unit (Table 1). A forwarder load consisted of 150 or fewer logs. For the grapple skidder, the number of twitches/treatment unit was calculated based on the harvest volume using an average twitch size of 3.0 tonnes. We assumed that the twitches were evenly distributed along the trails within the treatment unit. Time accumulated was multiplied by the hourly rate for each machine to calculate the total extraction costs per treatment unit.

Table 3. Harvest information for PCT and non-PCT stands by thinning treatment

\begin{tabular}{|c|c|c|c|c|c|c|c|c|}
\hline Plot & Block & Machine type & $\begin{array}{l}\text { Treatment } \\
\text { unit (ha) }\end{array}$ & $\begin{array}{l}\text { Prescription } \\
(\%)^{*}\end{array}$ & $\begin{array}{l}\text { BA removed } \\
(\%)\end{array}$ & $\begin{array}{l}\text { Harvest } \\
\text { time (min) }\end{array}$ & $\begin{array}{l}\text { Removal } \\
\text { (tonnes) }\end{array}$ & $\begin{array}{l}\text { Productivity } \\
\text { (tonnes/PMH) }\end{array}$ \\
\hline \multicolumn{9}{|c|}{ PCT Treatments } \\
\hline $1 \mathrm{~T}$ & $\mathrm{~T} 1$ & Harvester & 0.57 & 50 & 63 & 468 & 47.5 & 6.1 \\
\hline $3 \mathrm{~T}$ & $\mathrm{~T} 2$ & Harvester & 0.61 & 50 & 51 & 290 & 41.3 & 8.5 \\
\hline $4 \mathrm{~T}$ & $\mathrm{~T} 3$ & Harvester & 0.49 & 50 & 57 & 375 & 39.4 & 6.3 \\
\hline $7 \mathrm{~T}$ & $\mathrm{~T} 2$ & Harvester & 0.61 & 66 & 64 & 370 & 45.5 & 7.4 \\
\hline $10 \mathrm{~T}$ & $\mathrm{~T} 2$ & Harvester & 0.45 & 33 & 42 & 117 & 39.6 & 20.3 \\
\hline $11 \mathrm{~T}$ & $\mathrm{~T} 4$ & Harvester & 0.53 & 33 & 33 & 160 & 24.9 & 9.3 \\
\hline $12 \mathrm{~T}$ & $\mathrm{~T} 1$ & Harvester & 0.40 & 33 & 49 & 185 & 25.8 & 8.4 \\
\hline $15 \mathrm{~T}$ & $\mathrm{~T} 4$ & Harvester & 0.49 & 50 & 61 & 313 & 56.1 & 10.8 \\
\hline $17 \mathrm{~T}$ & $\mathrm{~T} 4$ & Harvester & 0.49 & 66 & 71 & 370 & 51.2 & 8.3 \\
\hline $21 \mathrm{~T}$ & $\mathrm{~T} 3$ & Harvester & 0.61 & 33 & 48 & 427 & 35.0 & 4.9 \\
\hline $23 \mathrm{~T}$ & $\mathrm{~T} 3$ & Harvester & 0.45 & 66 & 75 & 356 & 37.2 & 6.3 \\
\hline $27 \mathrm{~T}$ & $\mathrm{~T} 1$ & Harvester & 0.57 & 66 & 63 & 361 & 50.6 & 8.4 \\
\hline \multicolumn{9}{|c|}{ Non-PCT Treatments } \\
\hline $2 \mathrm{U}$ & U1 & Feller-buncher & 0.49 & 33 & 57 & 293 & 99.6 & 20.4 \\
\hline $4 \mathrm{U}$ & U1 & Feller-buncher & 0.40 & 66 & 77 & 330 & 58.1 & 10.6 \\
\hline $10 \mathrm{U}$ & U3 & Feller-buncher & 0.49 & 33 & 62 & 334 & 58.2 & 10.5 \\
\hline $13 \mathrm{U}$ & $\mathrm{U} 2$ & Feller-buncher & 0.61 & 33 & 63 & 626 & 74.5 & 7.1 \\
\hline $16 U$ & U3 & Feller-buncher & 0.57 & 66 & 80 & 509 & 90.2 & 10.6 \\
\hline $18 \mathrm{U}$ & U2 & Feller-buncher & 0.65 & 66 & 79 & 542 & 125.4 & 13.9 \\
\hline $22 \mathrm{U}$ & $\mathrm{U} 2$ & Feller-buncher & 0.71 & 50 & 68 & 509 & 125.7 & 14.8 \\
\hline $24 \mathrm{U}$ & U3 & Feller-buncher & 0.53 & 50 & 68 & 448 & 94.1 & 12.6 \\
\hline $27 \mathrm{U}$ & U1 & Feller-buncher & 0.49 & 50 & 69 & 285 & 66.9 & 14.1 \\
\hline
\end{tabular}

${ }^{*}$ Removal of standing softwood volume. 
Table 4. Hourly machine rates used in this analysis. Common hourly rates are represented by the range of values.

\begin{tabular}{lll}
\hline Machine & Machine type & $\begin{array}{l}\text { Hourly rate } \\
\text { (USD \$ PMH }\end{array}$ \\
\hline Ponsse Ergo & Harvester & $121-161$ \\
Timberjack 1110 & Forwarder & $92-119$ \\
CAT 501 & Feller-Buncher & $103-135$ \\
John Deere 648 GIII & Grapple Skidder & $90-115$ \\
Prentiss 325 & Loader & 40 \\
Morbark Model 23 & Chipper & $62-94$ \\
\hline
\end{tabular}

Trucking costs to the mill in this region are USD $\$ 1.67 / \mathrm{km}$ (Benjamin 2014). Roundwood is generally transported in a wider radius than wood chips and therefore we assumed a round-trip distance of between 80 and $160 \mathrm{~km}$ for roundwood and 50 to $100 \mathrm{~km}$ for wood chips. The average load per truck was 35.1 tonnes for roundwood and 24.2 tonnes for wood chips. Based on personal communications with various logging contractors the average loading times for roundwood and wood chips were assumed to be 25 minutes and $35 \mathrm{~min}$ utes, respectively.

\section{Profit Calculation}

For the calculation of profit, we subtracted the unit cost of production from the product revenue. In PCT units where three products were produced, we averaged the revenue per tonne based on individual product recoveries. Product specific values were supplied by anonymous sources in the industry and consisted of spruce/fir sawlogs at USD $\$ 74.97 /$ tonne ( $\$ 68 /$ ton), spruce/fir pulpwood at $\$ 44.10 /$ tonne $(\$ 40 /$ ton), hardwood pulpwood at $\$ 55.13 /$ tonne ( $\$ 50 /$ ton), and biomass chips at $\$ 38.59 /$ tonne $(\$ 35 /$ ton). All product values are mill delivered prices. A second profit calculation included the costs for PCT at $\$ 445 /$ ha, the actual cost for PCT in 1986 (Bataineh et al. 2013).

\section{Analysis}

Data were analyzed using R (R Core Team 2012) and four additional analysis packages: car (Fox and Weisberg 2011), nlme (Pinheiro et al. 2012), gplots (Warnes et al. 2013) and multcomp (Hothorn et al. 2008)). Two linear mixed-effects models with a random intercept were developed to explain the variation in harvester and feller-buncher productivity. The original blocking of treatment units was included as a random effect while the actual removal, basal area, initial stand conditions, and hardwood content in each treatment unit were included as a fixed effect. The underlying model assumptions for linear regression (normality, equal variances) were all met and data were not transformed.

An analysis of variance in combination with Tukey HSD pairwise group comparison was used to compare the unit cost of production and profit between individual treatments that were thinned by the cut-to-length and whole-tree systems, respectively.

Data from the first plot thinned by each machine (plots $10 \mathrm{~T}$ and $10 \mathrm{U}$ ) were removed from further analysis as these plots were used as training plots for each operator.

\section{Results}

\section{Product Recovery}

Product recovery in PCT stands consisted of spruce/fir pulpwood, spruce/fir sawlogs and hardwood pulpwood (Table 5). Overall, $54 \%$ of the harvested volume consisted of sawlogs while $39 \%$ and $7 \%$ was spruce/fir pulpwood and hardwood pulpwood, respectively. In non-PCT stands, product recovery was $100 \%$ biomass chips of mixed species.

\section{Harvester Productivity in PCT Stands}

A linear mixed-effects model with a random intercept was developed for the harvester with the covariates of stand density before thinning (DENS), basal area (BA), hardwood component in the stand (HWC), actual removal in tonnes (REM), and piece size of merchantable trees (PIECE) (Equation 1, $\left.\mathrm{R}_{\text {fixed }}^{2}=0.36\right)$. The blocking factor $(\alpha)$ was included as a random effect. None of the covariates $\left(\mathrm{p}_{\text {DENS }}=0.456, \mathrm{p}_{\mathrm{BA}}=\right.$ $0.409, \mathrm{p}_{\mathrm{HWC}}=0.620, \mathrm{p}_{\mathrm{REM}}=0.662, \mathrm{p}_{\mathrm{PIECE}}=0.450$ ), or any of the interactions, were significant predictors for harvester productivity (PROD). The blocking factor ( $\alpha$ ) explains $42 \%$ of the random variation in harvester productivity. Average productivity across all three treatments was 7.7 tonnes/PMH (Fig. 2).

Table 5. Product recovery in PCT stands

\begin{tabular}{|c|c|c|c|c|c|c|}
\hline Plot & Block & $\begin{array}{c}\text { Prescription } \\
(\%)^{\star}\end{array}$ & $\begin{array}{l}\text { Spruce/Fir pulp } \\
\text { (tonnes) }\end{array}$ & $\begin{array}{c}\text { Spruce/Fir sawlogs } \\
\text { (tonnes) }\end{array}$ & $\begin{array}{l}\text { Hardwood pulp } \\
\quad \text { (tonnes) }\end{array}$ & $\begin{array}{c}\text { Total } \\
\text { (tonnes) }\end{array}$ \\
\hline $1 \mathrm{~T}$ & $\mathrm{~T} 1$ & 50 & 18.7 & 19.9 & 9.0 & 47.5 \\
\hline $3 \mathrm{~T}$ & $\mathrm{~T} 2$ & 50 & 17.6 & 22.7 & 1.0 & 41.3 \\
\hline $4 \mathrm{~T}$ & T3 & 50 & 23.7 & 14.9 & 0.8 & 39.4 \\
\hline $7 \mathrm{~T}$ & $\mathrm{~T} 2$ & 66 & 17.6 & 23.4 & 4.5 & 45.5 \\
\hline $10 \mathrm{~T}$ & $\mathrm{~T} 2$ & 33 & 17.7 & 21.9 & 0.0 & 39.6 \\
\hline $11 \mathrm{~T}$ & $\mathrm{~T} 4$ & 33 & 13.2 & 9.1 & 2.5 & 24.9 \\
\hline $12 \mathrm{~T}$ & $\mathrm{~T} 1$ & 33 & 7.3 & 10.0 & 8.5 & 25.8 \\
\hline $15 \mathrm{~T}$ & $\mathrm{~T} 4$ & 50 & 19.0 & 30.8 & 6.2 & 56.1 \\
\hline $17 \mathrm{~T}$ & $\mathrm{~T} 4$ & 66 & 11.5 & 36.4 & 3.4 & 51.2 \\
\hline $21 \mathrm{~T}$ & $\mathrm{~T} 3$ & 33 & 15.8 & 19.2 & 0.0 & 35.0 \\
\hline $23 \mathrm{~T}$ & $\mathrm{~T} 3$ & 66 & 14.0 & 22.0 & 1.2 & 37.2 \\
\hline $27 \mathrm{~T}$ & $\mathrm{~T} 1$ & 66 & 16.0 & 34.6 & 0.0 & 50.6 \\
\hline
\end{tabular}

${ }^{\star}$ Removal of standing softwood volume. 


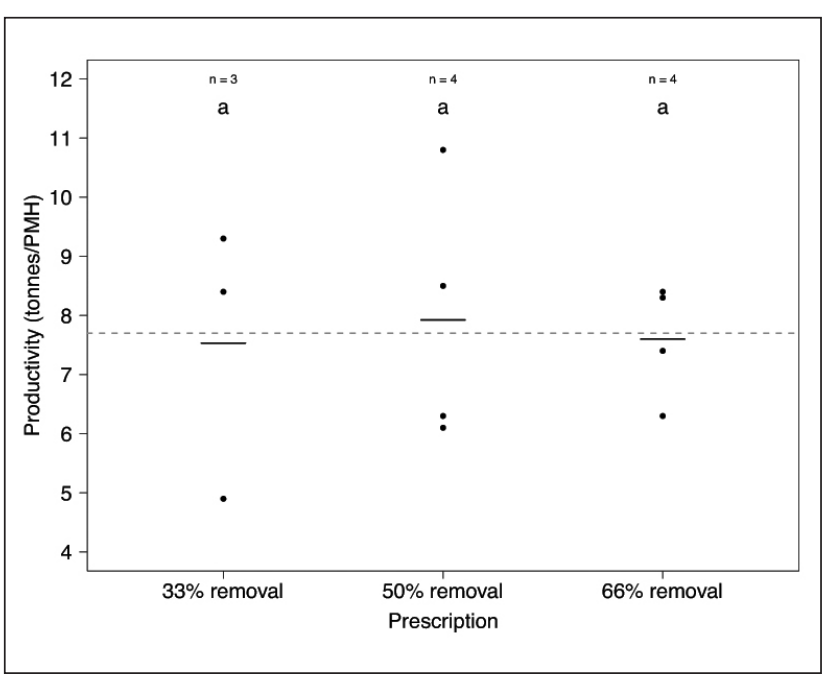

Fig. 2. Harvester productivity in PCT stands for three different treatments. The dashed line represents overall mean productivity, while the solid black lines represent the average productivity for each prescription. Treatments with the same letter are not significantly different from each other.

$$
\text { (1) } \begin{aligned}
& P R O D=-1.115+0.010 \times D E N S-0.635 \times B A-0.095 \\
& \times H W C+0.045 \times R E M+125.480 \times \text { PIECE }+\propto
\end{aligned}
$$

\section{Feller-Buncher Productivity in Non-PCT Stands}

A linear mixed-effects model with a random intercept was developed for the feller-buncher with the covariates of stand density before thinning (DENS), basal area (BA), hardwood component (HWC), and actual removal in tonnes (REM) (Equation 2, $\mathrm{R}_{\text {fixed }}^{2}=0.14$ ). The blocking factor $(\alpha)$ was included as a random effect. None of the covariates $\left(\mathrm{p}_{\mathrm{DENS}}=\right.$ $0.770, \mathrm{p}_{\mathrm{BA}}=0.915, \mathrm{p}_{\mathrm{HWC}}=0.877, \mathrm{p}_{\mathrm{REM}}=0.137$ ) or any of the interactions were significant predictors for feller-buncher productivity (PROD). The blocking factor ( $\alpha$ ) explains $90 \%$ of the random variation in feller-buncher productivity observed. Average productivity across all three treatments was 13.0 tonnes/PMH (Fig. 3).

$$
\text { (2) } \begin{aligned}
& P R O D=4.379-0.001 \times D E N S-0.052 \times B A+0029 . \\
& \times H W C+0.172 \times R E M+\propto
\end{aligned}
$$

\section{Unit Cost of Production}

The unit cost of production of roundwood from PCT stands ranged from USD \$20.56/tonne to \$50.66/tonne with an average of $\$ 33.46 /$ tonne. Biomass harvest costs from non-PCT stands ranged from $\$ 15.08 /$ tonne to $\$ 34.08 /$ tonne with an average of $\$ 22.33 /$ tonne. An analysis of variance in combination with Tukey HSD pairwise group comparison showed that there is no difference in unit cost of production between individual prescriptions within PCT $(\mathrm{p}=0.309)$ and nonPCT $(p=0.672)$ stands, respectively. However, there are differences $(\mathrm{p}=5.86 \mathrm{e}-04)$ between PCT and non-PCT stands (Fig. 4). The unit cost of production in PCT and non-PCT treatment units of the same prescription are different from each other with the exception of the $66 \%$ removal prescription. In that prescription there is no difference between the unit cost of production in PCT and non-PCT stands.

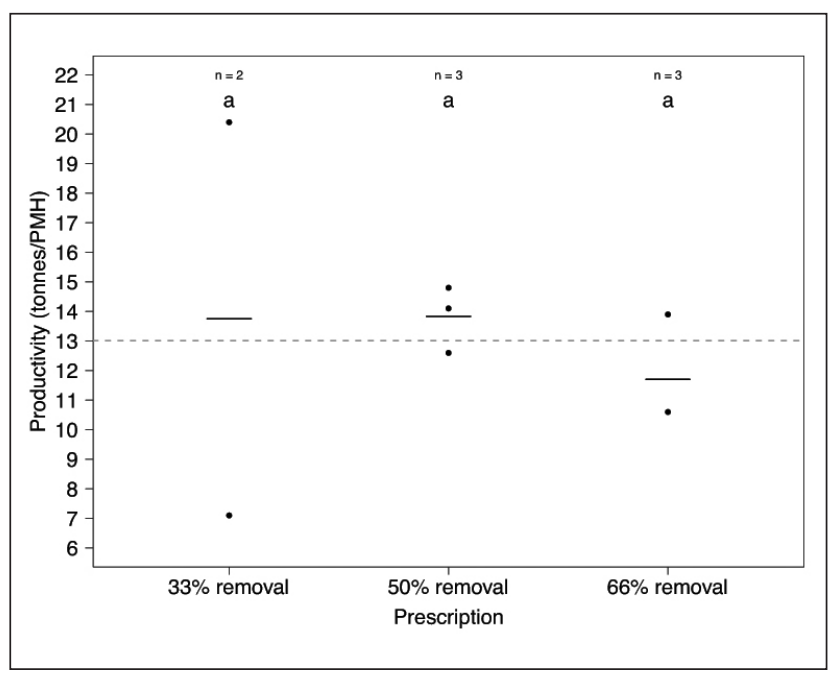

Fig. 3. Feller-buncher productivity in non-PCT stands for three different treatments. The dashed line represents overall mean productivity, while the solid black lines represent the average productivity for each prescription. Treatments with the same letter are not significantly different from each other.

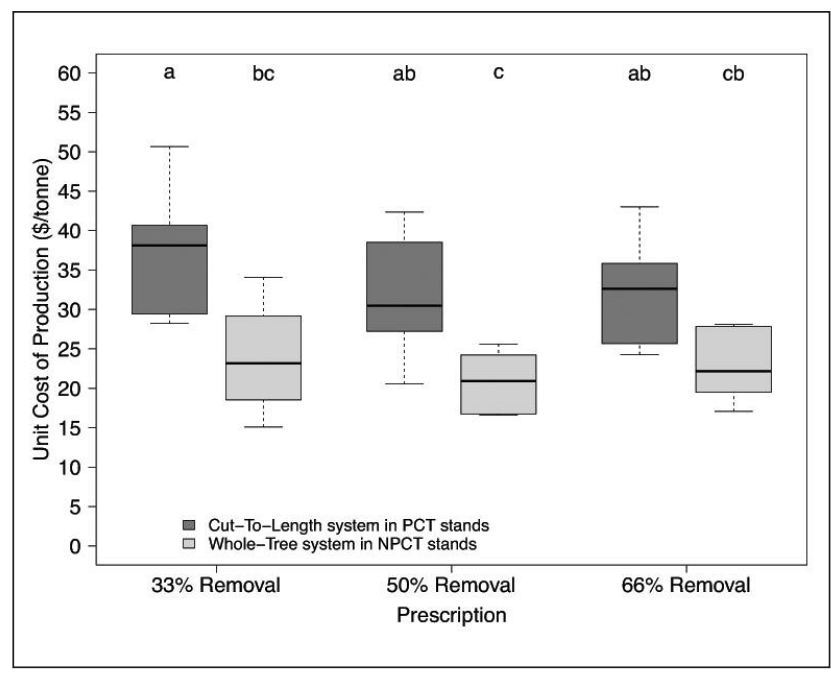

Fig. 4. Boxplot of unit cost of production ( $\$ /$ tonne) of roundwood and biomass from PCT and non-PCT stands trucked and delivered to a mill. Treatments with the same letter above their box have means that are not significantly different from each other. Bold lines represent the median productivity. The upper and lower whiskers represent the minimum and the maximum, respectively.

\section{Profit}

The profits for roundwood from PCT stands ranged from USD $\$ 10.37 /$ tonne to $\$ 42.45 /$ tonne. Profits on wood chips from non-PCT stands ranged from $\$ 4.51 /$ tonne to $\$ 23.51 /$ tonne. An analysis of variance in combination with Tukey HSD pairwise group comparison showed that there is no difference in profit between individual prescriptions within PCT $(\mathrm{p}=0.086)$ and non-PCT $(\mathrm{p}=0.672)$ stands, respectively (Fig. 5). Profits between PCT and non-PCT stands are not different from each other with the exception of 


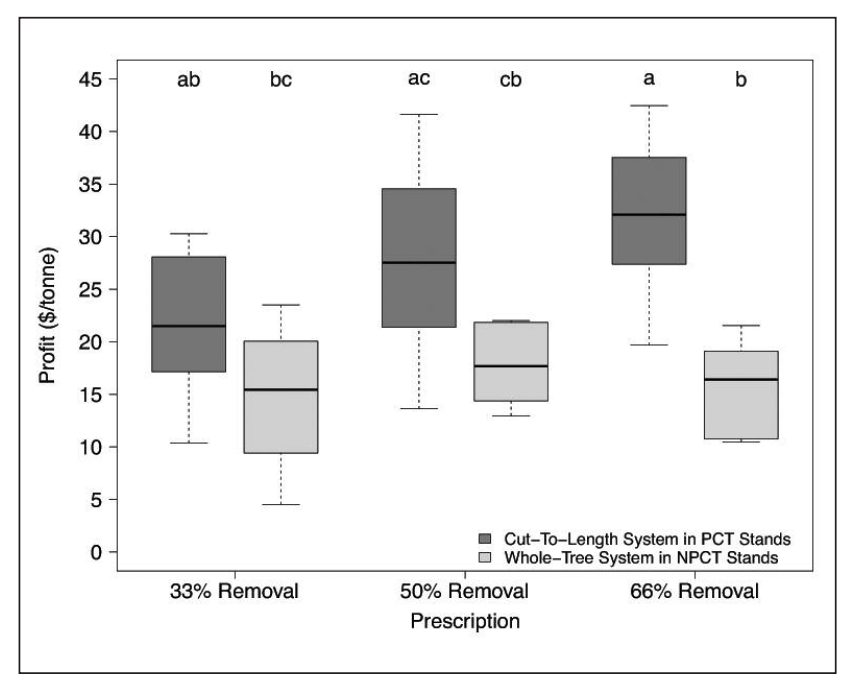

Fig. 5. Boxplot of profits ( $\$ /$ tonne) of roundwood and biomass from PCT and non-PCT stands trucked and delivered to a mill. Initial costs for PCT treatment have not been discounted for. Treatments with the same letter above their box have means that are not significantly different from each other. Bold lines represent the median productivity. The upper and lower whiskers represent the minimum and the maximum, respectively.

profits from the $66 \%$ removal prescription $(\mathrm{p}=0.003)$. The average profits in PCT and non-PCT stands across all treatments were $\$ 27.59 /$ tonne and $\$ 16.26 /$ tonne, respectively.

A second profit calculation included the costs for PCT at $\$ 445 /$ ha. Without discounting for any interest rate, the results of an analysis of variance show that there is no difference between the profit achieved from harvesting roundwood in PCT stands or biomass chips from non-PCT stands with the same prescription (Fig. 6). The only difference $(\mathrm{p}=0.024)$ exists between the profit gained from harvesting roundwood in PCT stands of a 33\% removal and 66\% removal prescription.

\section{Discussion \\ Harvester and Feller-Buncher Productivity}

Research indicates that several factors influence the productivity of harvesting equipment. Stand density, for example, has been reported to be an influential factor on feller-buncher and harvester productivity (Gingras 1988, Eliasson 1999). In our study we found that neither stand density, basal area, hardwood component, actual removal, or piece size explain the variation in machine productivity. We used a linearmixed effects model to test for explanatory variables and found that stand density had no explanatory significance even though we operated in stand densities ranging from 1309 to 2594 and 3211 to 5496 trees/ha for harvester and fellerbuncher, respectively.

Eliasson (1999) reported that stand density affects harvester productivity the most when harvesting large diameter trees. The reasoning was that directional felling of large trees is more difficult and time-consuming in high density stands. Our harvest site consists of only small-diameter trees with piece sizes of less than $0.17 \mathrm{~m}^{3}$. We believe that there is no increased difficulty of felling such small trees. One contribut-

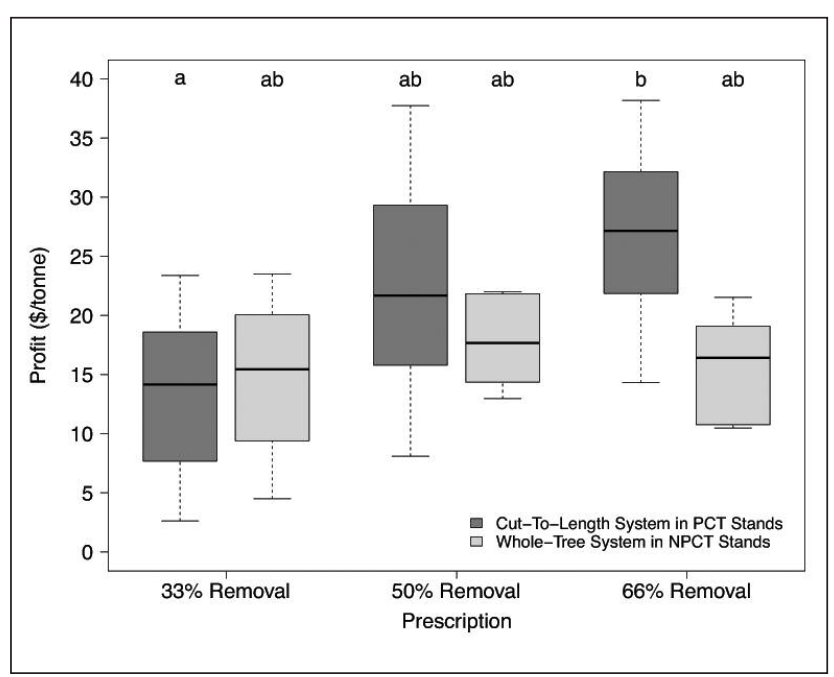

Fig. 6. Boxplot of profits ( $\$ /$ tonne) of roundwood and biomass from PCT and non-PCT stands trucked and delivered to a mill. Initial costs for PCT treatment have been accounted for, but do not include any interest. Treatments with the same letter above their box have means that are not significantly different from each other. Bold lines represent the median productivity. The upper and lower whiskers represent the minimum and the maximum, respectively.

ing factor to this assertion is that we used a trail spacing of $15.2 \mathrm{~m}$ which reduces the distance a machine has to reach into the matrix and therefore allows trees to be pulled or lifted onto the trail more easily.

The amount of volume removed has been shown in other studies to influence harvester and feller-buncher productivity (Légère and Gingras 1998, Li et al. 2006,). Three different thinning prescriptions $(33 \%, 50 \%$, and $66 \%$ of the standing softwood volume) were implemented in our study. Model results showed that the actual removal intensity did not influence productivity for either harvest system. There may be three reasons for this result: (1) technological advancement of equipment since the 1990s and 2000s when these studies were conducted; (2) use of highly skilled and experienced operators; or, (3) marking of crop trees prior to harvest. The latter might have reduced the time spent making harvesting decisions and hence increased the productivity, especially in the low removal treatment. However, results from an early commercial thinning study in Maine showed that there is no difference in time consumption for common softwood and hardwood species between 10 and $28 \mathrm{~cm}$ dbh (Hiesl and Benjamin 2012). Due to the blocking of treatment units, the same range of stand conditions can be found within each prescription. The effect of blocking these treatment units can be seen in the high explanatory power of $42 \%$ and $90 \%$ of the random variation for harvester and fellerbuncher productivity, respectively. Taking into consideration all the factors mentioned before, we believe that small tree size is the major reason why there is no difference in productivity between individual prescriptions. Both harvester and feller-buncher productivity compare well with previous results of an early commercial thinning study in a similar stand in Maine (Benjamin et al. 2013) and productivity study results of Hiesl (2013). 
Commercial thinnings in this region have been observed by the authors to exceed $50 \%$ of the basal area. In our study, this would be reflected in the $33 \%$ and $50 \%$ removal prescriptions. The removal intensities in the $66 \%$ prescription are extreme values that will be used to gain knowledge about tree and stand responses to such measures. Since a higher removal intensity has been linked to a greater number of softwood regeneration (Olson et al. 2014), we are hopeful that this extreme entry will result in an abundance of regeneration. A treatment based on softwood volume removal instead of basal area removal was chosen so that stand and individual tree responses could be compared to results from the Commercial Thinning Research Network (Clune 2013). Equipment operators in the current study had between seven and thirty years of experience working in similar stand conditions. Research indicates that operators can have a large effect on machine productivity ( Kärhä et al. 2004, Purfürst and Erler 2011, Hiesl 2013, Hiesl and Benjamin 2013a,). The effect of operators on harvester productivity has been as large as 40\% (Kärhä et al. 2004). A recent study in Maine showed that the effect of operator, machine, and stand and site conditions in small-diameter timber stands is up to $7 \%$ for harvesters, $54 \%$ for forwarders and 30\% for grapple skidders (Hiesl 2013). For a feller-buncher, this effect can be as high as 32\% (Hiesl and Benjamin 2013a). As this study was conducted only at one location in Maine with only one operator for each machine, the results are of limited use in other areas and therefore this research should be seen as a case study. Further research is needed to investigate the variation in machine productivity in different locations and with a multitude of operators.

\section{Unit Cost of Production}

In this study we made a conscious decision to use two different harvesting systems for PCT and non-PCT stands of the same age to show an option for treatment of high-density, small-diameter stands with a comparison of unit cost of production to PCT stands. This decision was based on unpublished results from an early commercial thinning trial by Benjamin et al. (2013) which showed that a harvester in non-PCT stands has an increased number of delays due to thrown chains and breaking trees. Similar results have been seen in unpublished data from a harvest productivity study by Hiesl (2013). Due to increased downtime of a harvester in highdensity, small-diameter stands, we can expect that the thinning of such stands with a cut-to-length system is more costly than the thinning of PCT stands and subsequently also more costly than the use of a whole-tree system. We would further expect a loss of harvest volume, as only roundwood would be processed.

The lack of differences between the unit cost of production between individual prescriptions of PCT and non-PCT stands, respectively, is not surprising, as the there was no difference in productivity either. Also not surprising is the lower unit cost of production for biomass chips. This is due to two reasons: (1) the higher productivity of the thinning and extraction equipment; and, (2) the use of whole-trees which increased the total volume harvested. Within each prescription the unit cost of production of roundwood is higher than the one for biomass chips. One exception may be found in the prescription with the highest removal intensity, where the unit cost of production for roundwood and biomass is not different from each other. One reason for this might be the wide range of actual removals of roundwood and biomass. Since common practice in this region is to commercially thin up to $40 \%$ of the basal area, this observed equality of unit cost production in the $66 \%$ removal prescription, however, is not meaningful to the industry, as this represents a basal area removal of between $63 \%$ and $80 \%$.

\section{Profit}

Proper reasoning would imply that producing a higher value product from PCT stands should result in a higher profit. Except for the $66 \%$ removal prescription however, there is no statistical difference between the profits per tonne for any of the other prescriptions. Our explanation for this is twofold: (1) on average, almost twice as much biomass chips than roundwood logs were harvested from the individual treatment units. Such a surplus was enough to balance the revenue from more valuable roundwood logs in the 33\% and 50\% removal prescription; (2) the $66 \%$ removal prescription produced the largest amount of sawlogs across all prescriptions. With sawlogs being the most valuable product, we know that the surplus of biomass chips in that prescription was not enough to balance the revenue.

All these profit calculations, however, were made without including the costs for the initial PCT. When accounting for the costs of PCT without discounting for any interest rate, the results show that the profit is the same for roundwood from PCT stands and biomass chips from non-PCT stands. Once the PCT costs are discounted by any interest rate, the profit of roundwood from PCT stands will decrease even further. These results support the conclusion that high-density stands that have not been treated with PCT can receive a first thinning at the same time that PCT stands would and still generate a profit. However, it has to be acknowledged that one commercial thinning is not the end of forest management in these stands. Rather, it is another step towards creating a softwood stand consisting of sawlog quality trees. Because of that, other treatments will occur in the future and therefore discounting for the initial investment of PCT at the first commercial thinning might not be completely appropriate. The costs for PCT rather need to be discounted for across the total rotation length to investigate whether or not there is a financial gain on doing such a treatment.

Calculations by Bataineh et al. (2013) clearly show a higher net present value (NPV) for PCT stands in the Austin Pond study. One major reason for this outcome is that their analysis included sawlogs and pulpwood only. Their calculations did not account for biomass chips, which was the sole product in non-PCT stands in this study. Another reason for their high NPV values is that they used average stumpage values that were much higher than what would have been economically feasible at this site. When looking at the numbers presented in the current study, it becomes clear that the NPV of non-PCT stands is at least as high as the one for PCT stands if not even higher.

\section{Conclusion}

Several studies show that the use of PCT increases individual tree growth and returns sawlog-sized trees in a shorter period of time (Pitt and Lanteigne 2008, Weiskittel et al. 2009, Olson et al. 2012, Pitt et al. 2013a). Based on stumpage rates and pre- 
miums paid for thinned wood, the NPV for PCT stands is higher than for non-PCT stands ( Bataineh et al. 2013, Pitt et al. 2013b,). However, results from our study show that the unit cost of production in PCT and non-PCT stands are similar. The increased product volume in non-PCT stands makes up for the lower product value of biomass chips and roundwood and leads to similar profits. The outcome of this case study, therefore, is that a first thinning of high-density, smalldiameter stands such as the described non-PCT stands using the whole-tree system is economically feasible. One prerequisite, however, is the existence of a biomass market within a $100 \mathrm{~km}$ radius. What needs to be investigated in the future is the individual tree response and the regeneration following such thinnings, so that the effectiveness of these treatments can be evaluated.

\section{Acknowledgments}

We would like to thank Plum Creek Timber Company for their ongoing support of this long-term study. Special thanks go to John Ackley of Plum Creek in Bingham, Maine, for his help and support during the study. We would also like to thank the three logging contractors and their crews for their patience and help during the harvest, as well as Derek Brockmann for his help with managing the harvests and data collection. We would like to express our gratitude to Dr. Robert Wagner for all the discussions about this research project that helped to make a well-rounded article. This research was funded by the Cooperative Forestry Research Unit and Maine Agricultural and Forest Experiment Station (Publication No. 3407). Additional funding was provided by the FarmBio3 project ("Distributed On-Farm Bioenergy, Biofuels and Biochemicals (FarmBio3) Development and Production via Integrated Catalytic Thermolysis", NIFA Award No. 2012-1000820271, ARS Project No. 1935-41000-082-15A, ARS-UMaine Cooperative Agreement No. 59-1935-3-003) and the Northeastern States Research Cooperative through funding made available by the USDA Forest Service. The conclusions and opinions in this paper are those of the authors and not the NSRC, the Forest Service, or the USDA.

\section{References}

Balmer, W.E., K.A. Utz and O.G. Langdon. 1978. Financial returns from cultural work in natural loblolly pine stands. South. J. Appl. For. 2(4): 111-117.

Bataineh, M.M., R.G. Wagner and A.R. Weiskittel. 2013. Longterm response of spruce-fir stands to herbicide and precommercial thinning: observed and projected growth, yield, and financial returns in central Maine, USA. Can. J. For. Res. 43(4): 385-395. Available at: http://www.nrcresearchpress.com/doi/abs/10.1139/cjfr2012-0343 [accessed 31 July 2013].

Benjamin, J.G. 2014. Operational \& Economic Aspects of Biomass Harvesting: There is No Free Lunch in the Woods. Presentation at New England Society of Foresters 2014 Winter Meeting, March $25^{\text {th }}$, 2014, Nashua, NH, USA.

Benjamin, J.G., R.S. Seymour, E. Meacham and J.S. Wilson. 2013. Impact of Whole-Tree and Cut-to-Length Harvesting on Postharvest Condition and Logging Costs for Early Commercial Thinning in Maine. North. J. Appl. For. 30(4): 149-155.

Brinker, R.W., J. Kinard, B. Rummer and B.L. Lanford 2002. Machine rates for selected forest harvesting machines. Circular 296 (revised), Alabama Agricultural Experiment Station, pp. 1- 32. Auburn, AL, USA.
Brissette, J.C., R.M. Frank Jr., T.L. Stone and T.A. Skratt. 1999. Precommercial thinning in a northern conifer stand: 18-year results. For. Chron. 75(6): 967-972.

Clune, P.M. 2013. Growth and development of Maine spruce-fir forests following commercial thinning. Master Thesis. University of Maine-School of Forest Resources, Orono, ME, USA.

Eliasson, L. 1999. Simulation of Thinning with a Single-Grip Harvester. Forest Science 45(1): 26-34.

Fox, J. and S. Weisberg. 2011. An $\{\mathrm{R}\}$ Companion to Applied Regression. $2^{\text {nd }}$ ed. Sage Publications, Inc., Thousand Oaks, CA, USA. Gingras, J.-F. 1988. The effect of site and stand factors on fellerbuncher performance. Technical Report TR-84. Forest Engineering Research Institute of Canada (FERIC), Pointe Claire, PQ, Canada.

Hiesl, P. 2013. Productivity Standards for Whole-Tree and Cut-ToLength Harvesting Systems in Maine. Master Thesis. University of Maine-School of Forest Resources, Orono, ME, USA.

Hiesl, P. and J.G. Benjamin. 2012. Cycle time analysis of harvesting equipment from an early commercial thinning treatment in Maine. Proceedings of the 35th Council on Forest Engineering: Engineering New Solutions for Energy Supply and Demand. J. Roise and A. Hassan (eds). Council on Forest Engineering, September, 12, 2012, New Bern, NC, USA.

Hiesl, P. and J.G. Benjamin. 2013a. A multi-stem feller-buncher cycle-time model for partial harvest of small diameter wood stands. Intern. J. For. Engin. 24(2): 101-108.

Hiesl, P. and J.G. Benjamin. 2013b. Harvesting Equipment Cycle Time and Productivity Guide for Logging Operations in Maine. Miscellaneous Publications 762, Maine Agricultural and Forest Experiment Station, Orono, ME, USA.

Hothorn, T., F. Bretz and P. Westfall. 2008. Simultaneous Inference in General Parametric Models. Biometrical J. 50(3): 346-363.

Kärhä, K., E. Rökkö and S.-I. Gumse. 2004. Productivity and cutting costs of thinning harvesters. Intern. J. For. Engin. 15(2): 43-56. Légère, G. and J.-F. Gingras. 1998. Evaluation of methods of harvesting with protection of small merchantable stems. Technical Report-124. Forest Engineering Research Institute of Canada (FERIC), Pointe Claire, P.Q. Canada.

Li, Y., J. Wang, G. Miller and J. McNeel. 2006. Production economics of harvesting small diameter hardwood stands in central Appalachia. For. Prod. J. 56(3): 81-86.

McCaskill, G.L., W.H. McWilliams, C.J. Barnett, M.A. Hatfield, C.M. Kurtz, R.S. Morin, W.K. Moser, C.H. Perry and C.W. Woodall. 2011. Maine's Forests 2008. Resource Bulletin NRS-48, U.S. Department of Agriculture Forest Service, Northern Research Station, Newtown, PA, USA.

Newton, M., E.C. Cole, D.E. White and M.L. McCormack. 1992a. Young Spruce-Fir Forests Released by Herbicides I. Response of Hardwoods and Shrubs. North. J. Appl. For. 9: 126-130.

Newton, M., E.C. Cole, M.L. McCormack and D.E. White. 1992 b. Young Spruce-Fir Forests Released by Herbicides II. Conifer Response to Residual Hardwoods and Overstocking. North. J. Appl. For. 9: 130-135.

Olson, M.G., R.G. Wagner and J.C. Brissette. 2012. Forty years of spruce-fir stand development following herbicide application and precommercial thinning in central Maine, USA. Can. J. For. Res. 42(1): 1-11. Available at: http://www.nrcresearchpress.com/doi/abs/ 10.1139/x11-132 [accessed 31 July 2013].

Olson, M.G., S.R. Meyer, R.G. Wagner and R.S. Seymour. 2014. Commercial thinning stimulates natural regeneration in spruce-fir stands. Can. J. For. Res. 44(1): 173-181.

Pekol, J., A.R. Weiskittel, R.S. Seymour and R.G. Wagner. 2012. Influence of Commercial Thinning on Stand \& Tree-Level Mortality Patterns of Balsam Fir and Red Spruce Forests in Maine with \& without Precommercial Thinning. In: B.E. Roth (ed.). Cooperative Forestry Research Unit: 2011 Annual Report. University of Maine, Orono. ME, USA. 
Pelletier, G. and D.G. Pitt. 2008. Silvicultural responses of two spruce plantations to midrotation commercial thinning in New Brunswick. Can. J. For. Res. 38(4): 851-867. Available at: http:// www.nrcresearchpress.com/doi/abs/10.1139/X07-173 [accessed 4 February 2013].

Pinheiro, J., D. Bates, S. DebRoy, D. Sarkar and R Development Core Team. 2012. nlme: Linear and Nonlinear Mixed Effects Models. R package version 3.1-104

Pitt, D. and L. Lanteigne. 2008. Long-term outcome of precommercial thinning in northwestern New Brunswick: Growth and yield of balsam fir and red spruce. Can. J. For. Res. 38(3): 592-610. Available at: http://www.nrcresearchpress.com/doi/abs/10.1139/X07-132 [accessed 13 August 2013].

Pitt, D.G., L. Lanteigne, M.K. Hoepting and J. Plamondon. 2013a. Effects of precommercial thinning on the forest value chain in northwestern New Brunswick: Part 1-Roundwood production and stumpage value. For. Chron. 89(4): 446-457.

Pitt, D., L. Lanteigne, M.K. Hoepting, J. Plamondon, I. Duchesne, P. Bicho and G. Warren. 2013b. Effects of precommercial thinning on the forest value chain in northwestern New Brunswick: Part 6Estimating the economic benefits. For. Chron. 89(4): 502-511.

Plamondon, J. and D.G. Pitt. 2013. Effects of precommercial thinning on the forest value chain in northwestern New Brunswick: Part 2-Efficiency gains in cut-to-length harvesting. For. Chron. 89(4): 458-463.

Purfürst, F.T. and J. Erler. 2011. The human influence on productivity in harvester operations. Intern. J. For. Engin. 22(2): 15-22.

$\mathrm{R}$ Core Team 2012. $R$ : A language and environment for statistical computing. R Foundation for Statistical Computing, Vienna, Austria.
Saunders, M.R., R.G. Wagner and R.S. Seymour. 2008. Thinning Regimes for Spruce-Fir Stands in the Northeastern United States and Eastern Canada. Orono, ME, USA: Cooperative Forestry Research Unit, Orono, ME, USA.

Seymour, R.S. 1995. The northeast region. In: J.W. Barrett (ed.). Regional Silviculture of the United States. 3rd ed. pp. 31-79. John Wiley \& Sons, Inc., New York, NY, USA.

Smith, D.M. 1986. The Practice of Silviculture. 8th ed. John Wiley \& Sons, Inc., New York, NY, USA.

Tian, S. 2002. Effect of Precommercial Thinning on Root Develpment and Root and Butt Decay Incidence of Red Spruce and Balsam Fir. University of Maine, Orono, MW, USA. .

Warnes, G.R, B. Bolker, L. Bonebakker, R. Gentleman, W. Huber, A. Liaw, T. Lumley, M. Maechler, A. Magnusson, S. Moeller, M. Schwartz and B. Venables. 2013. Gplots: Various R programming tools for plotting data. R package version 2.11.0. http://cran.r-project.org/package-gplots

Weiskittel, A.R., L.S. Kenefic, R.S. Seymour and L.M. Phillips. 2009. Long-Term Effects of Precommercial Thinning on the Stem Dimensions, Form and Branch Characteristics of Red Spruce and Balsam Fir Crop Trees in Maine, USA. Silva Fenn. 43(3): 397-409.

Zhang, S.Y., G. Chauret, G., D.E. Swift and I. Duchesne. 2006. Effects of precommercial thinning on tree growth and lumber quality in a jack pine stand in New Brunswick, Canada. Can. J. For. Res. 36(4): 945-952. Available at: http://www.nrcresearchpress.com/ doi/abs/10.1139/x05-307 [accessed 21 August 2013]. 